\title{
ТСM \\ Female voices marginalised in media coverage of science in Uganda, both as authors and sources
}

\section{Ivan Nathanael Lukanda}

\begin{abstract}
Studies on women's marginalisation as authors and sources of science stories in the media in developing countries are few, and fewer in the context of genetically modified organisms (GMOs). Using feminist media theory, this study surmises that women are accordingly underrepresented in GMO stories. Based on a content analysis of 317 stories published in two Ugandan newspapers, findings indicate that chances of females being published as authors and sources increase if they collaborate with a male. There is a need for female scientists to collaborate with male counterparts and journalists to increase their visibility in the media in an agricultural sector where women are great contributors to the labourforce.
\end{abstract}

\section{Keywords}

DOI

Introduction
Science and media; Women in science

https://doi.org/10.22323/2.20020211

Submitted: 23rd July 2020

Accepted: 13th January 2021

Published: 5th May 2021
The argument that women are underrepresented in the media in many aspects of life has emerged, gained audience, evolved and persisted over the years [Ceci, Williams and Barnett, 2009]. Gender discrimination extends to fields of science, overtly and covertly. While women have made educational advancement in law and business, women's progress in "science areas", including biotechnology, and the "workplace [is] still slower" [Hill, Corbett and St. Rose, 2010, p. 39]. The current study uses an analysis of biotechnology — artificial breeding to make genetically modified organism (GMOs) as food, feed or fodder [Bayer Global, 2020] - stories in two Ugandan newspapers to explain how women are under-represented in the coverage of science. Yet, females account for $76 \%$ of the country's workforce in the agricultural sector, the pillar of the economy [World Bank, 2019]. Subsequently, this study is justified on grounds that any application of science in the sector should include women, and any disregard for them is not only unfair to women and society, but also denies the country the opportunity to capture women's perspectives on a technology whose application in producing food has raised global scientific, political, economic and religious questions. 
While the number of women in the academic field of biotechnology is increasing, men still dominate the biotechnology industry, including the influential scientific advisory boards [McCook, 2013]. The underrepresentation of women has also been reported in the case of dental journal editorial boards [Ioannidou and Rosania, 2015].

A recent global study demonstrates that women membership in national academies of science is about $12 \%$ [Ngila et al., 2017]. In that study, Cuba has the highest number of female members in its national academy with $27 \%$. In Africa, South African women scientists are best represented at $24 \%$. Tanzania has $4 \%$ and Uganda 13\% [Ngila et al., 2017, pp. 3-4]. Another global study that captured only Egypt and South Africa on the African content reveals that gender stereotypes tend to associate science with men rather than women, and such labels are natured from childhood [Miller, Eagly and Linn, 2015]. Gender bias bars women from "belonging" and this extends to their participation in science communication engagements [Moss-Racusin et al., 2018, p. 1]. Indeed, publications from male authors are perceived to be of greater scientific quality than those from their female counterparts [Knobloch-Westerwick, Glynn and Huge, 2013]. While governments in East Africa generally promote women's involvement in science, only Ethiopia and Rwanda have policies that included women in science, technology and innovation [Hafkin, 2016]. Moreover, implementation of such policies is impeded by social-cultural attitudes and minimal support in Eastern Africa where patriarchy, cultural-religious practices, and widespread gender stereotypes are entrenched. Therefore, general discrimination of women is rife, manifests in different forms, and is reinforced by several factors.

Socio-cultural contexts tend to reproduce the dominant gender discourses [Ceci, Williams and Barnett, 2009; Mendick and Moreau, 2013; Walsh, 2015].

Consequently, gender bias in society is observed in the socio-scientific systems. The bias seems based on Rossiter's [1993] "Matilda effect" - systematic denial of credit to women as opposed to Merton's [1968] "Mathew effect" — systematic recognition of men and the famous. As a result, women tend to get fewer research grants, fewer fellowship awards as their proposals tend to be downgraded [Suarez-Villa, 2000], are less likely to be promoted and to hold leadership positions [Knobloch-Westerwick, Glynn and Huge, 2013]. Indeed, both men and women were less likely to hire a female job applicant in favour of a male with a matching ability based on profile [Steinpreis, Anders and Ritzke, 1999]. In terms of collaboration, women are found to be more inclusive in their choice of scientific collaborators than men [Araújo et al., 2017]. Feminists attribute women's marginalisation to a culture rooted in "masculine news values" that favour men's views thereby allocating women a lower status as citizens [Ross and Carter, 2011, p. 1148]. It seems that women's job-suitability is often measured against men's abilities, thereby finding women wanting in a largely patriarchal society.

A related study has highlighted the challenge of "vertical segregation" in the news media where women remain largely absent from key editorial decision-making roles [North, 2016, p. 356]. Armstrong [2004, p. 139] argues that the dominance of men in the newsroom ensures that "male sources and subjects" are given "more mentions" and are "placed more prominently in news stories". The masculinist discursive views seem to blind the decision makers to the disadvantage women face. However, one scholar asserts that "feminists have historically been too critical 
of the natural sciences", leading to de-contexualisation and politicisation rather than suggesting how women can participate in scientific research [Kenney, 2018, p. 182]. Moreover, other researchers have concluded that individual circumstances drive most women out of science fields, even when they have qualified to the highest levels. Therefore, beyond biological factors, "women's preferences, potentially representing both free and constrained choices, constitute the most powerful explanatory factor" [Ceci, Williams and Barnett, 2009, p. 218].

While attempts have been made to increase women representation, such efforts largely present women scientists as decorations in photographs with their male heroes [González et al., 2017]. In the context of climate change and Uganda, "women as sources ranked third in importance after men and anonymous sources" [Semujju, 2015, p. 658]. The use of women as sources of information increases female voices in the public sphere [Walsh, 2015], as female journalists are more likely to cite women sources than their male counterparts on any subject [Armstrong, 2004]. Besides, one study suggests that only nutrition magazines are likely to emphasise women as sources and targets of information. Nutrition magazines tend to describe women as burden bearers for families and that women should be educated about defending infants against the possible negative impacts of GMOs [Rosenberger, 2009]. However, Rosenberger's study does not state whether such magazines are likely to hire women reporters to achieve their goal. A related study shows that women "express greater concern about GM organisms and are less likely to approve GMOs for consumption than men" [Sarathchandra and McCright, 2017, p. 3]. The permeability of science and society seems to be rooting women in their traditional care-giver role, shielding them from public life, and consequently locking them away from the media coverage on the subject of GMOs.

To demonstrate the gender imbalance in writing and sourcing about GMOs, this paper examines the coverage of GMOs in two Ugandan newspapers. The issue of GMOs has generated a lot of debate around the world [Bauer, 2002; Bhatta and Misra, 2016], and Uganda's media, especially in regard to its perceived commercial, health, environmental, ethical and regulatory challenges [Lukanda, 2018]. This paper is conceptualised around the feminist media theory, which has already been explored in studying women's representation in science [Blickenstaff, 2005; Ceci, Williams and Barnett, 2009; McIntosh, 2014; Miller, Eagly and Linn, 2015; González et al., 2017; Kenney, 2018], but not in respect to biotechnology stories, especially in the context of Uganda.

This study is justified on grounds that women contribute $50 \%$ of the agricultural labourforce in Sub-Saharan Africa [Food and Agricultural Organisation, 2011, p. 4], account for $76 \%$ of the workforce in Uganda's agricultural sector [World Bank, 2019], and contribute between $60 \%$ to $80 \%$ to the production of locally consumed food [Palacios-Lopez, Christiaensen and Kilic, 2015]. Moreover, with 44 million people at the current growth rate of 3.6\%, Uganda's population is expected to double by 2050, meaning the demand for food will keep increasing [Uganda Bureau of Statistics, 2019]. These statistics suggest that GMOs can become an option in an attempt to produce enough food for the population. As such, understanding women's contribution to science communication both as authors and sources, especially in the adoption of an agricultural technology becomes worthwhile. Further, women's contribution to the current controversy on adoption 
of GMOs has not been adequately documented, at least in a scholarly format, even though they are most likely to be affected by the technology by virtue of their participation in bigger numbers in the agricultural workforce. Besides, evidence suggests that where women are empowered to take decisions in agriculture, livelihood improves in the home [Sell and Minot, 2018]. The theory, research method and the results are discussed before concluding the article.

Feminist media theory explains gender and gendered power relations within text on communicative platforms. Beyond gender, the theory is concerned with justice for all races, sexuality, ethnicity, religion and class [Cuklanz, 2016]. By its political nature, feminist media theory questions processes of "hiring, production, distribution ... representation ... and ... reception" of news [Steiner, 2014, p. 359]. The theory has been adopted in studying representation of women in professions, including science. Chimba and Kitzinger [2010, p. 1] reveal that in science, engineering and technology, journalists focus on appearance of women scientists to "sex-up" the image of disciplines largely considered male spheres. Also, Shachar [2000] accuses journalists of using tokenism in their coverage of women scientists. However, some scholars reveal that journalistic action can be justified based on the unavailability of women as public experts, even in developed countries, such as Finland [Niemi and Pitkänen, 2017] and the United States of America [National Academies of Sciences, Engineering, and Medicine, 2020]. The underrepresentation is so much that interventions to increase gender bias literacy toward women in science have been necessary [Pietri et al., 2017].

Many factors contribute to women's underrepresentation as authors and sources in science in society. There are socio-economic factors that affect girls' performance at school more than the boys, and limit the girls' chances as experts in future [Shahidul and Zehadul Karim, 2015]. Indeed, Steinke [1998, p. 144] identifies three significant "socialising agents that contribute to the 'masculine image of science': school, home, and the media". The school environment is gender-biased about girls' ability in sciences; there are few role models in science classes; and women are hardly represented in science content. At home, hardly any discussion about science careers happens; the overprotective behaviour of parents discourages girls from participating in science challenges; and parents' labels of their children's inability in science work in combination to limit the number of women in science. Further, the media's emphasis of differences in performance to biological factors favouring boys' excellence in science lowers mothers' confidence in their girls' abilities. Yet, the tendency to use gender stereotyped images influence girls' perceptions of science and scientists [Steinke, 1998]. In the big bang theory, a paper based on situation comedy on professional roles, gender roles and intelligence of female scientists, McIntosh [2014] concludes that while societal stereotypes might be undermined in the course of entertainment, the comedy reinforces rather than challenges the stated status quo.

In light of those challenges, Blickenstaff [2005, p. 369] describes the progressive and persistent underrepresentation of women as a "leaky pipeline" that mostly filters out one sex as it allows the other to arrive at the end of the pipeline. Although scientists have argued that boys are more likely to be successful in science, feminist science critics have observed that it is the social nature of science that has "moored" leaky pipeline [Subramaniam, 2009, p. 951]. Giordano [2017, p. 1] suggests that 
rather than focus on the politics that keeps women out of science in the leaky pipeline, society should emphasise "passion for science", an attitude that allows people (women) who may not spend very long hours doing laboratory work to contribute to science in other ways, such as teaching future scientists. A literature review on attitudes toward science suggests that "gender, teachers, curricula, cultural" and related factors should be important pointers in finding motivations in raising pupils' interest in studying science [Osborne, Simon and Collins, 2003, p. 1049].

In the context of Uganda, cultural factors such as men fearing to marry women scientists scare girls away from taking science subjects and women from pursuing such careers [SEEK-GSP, 2016]. With sociocultural and ideological factors suggesting that girls will mostly be useful to their husbands and not the current family, most parents and/or guardians often prefer to defend the future of the clan by educating boys [Atekyereza, 2001]. A report highlights that only $48 \%$ of Ugandan adolescent girls had attended secondary school [Ministry of Education and Sports, 2017]. Another study indicates that many Ugandan girls start child bearing early and that $49 \%$ were married by age 18 [Uganda Bureau of Statistics, 2012]. Although Uganda developed its Science Policy in 2004, the number of females enrolling for science subjects at tertiary level remains low, and consequently the number female science researchers has remained below $30 \%$ [United Nations Educational, Scientific and Cultural Organisation, 2019]. A recent study emphasises that women face significant obstacles in science education because the country lacks effective policies to address the gender challenges [Odaga, 2020]. An intricate relationship between women and the government, society and the media replicates cultural narratives that are detrimental to women's involvement in public affairs [Maractho, 2019]. Although the number of female journalists has increased in Uganda, women continue to spend shorter time in the newsroom because of the aggressive nature of journalism that requires long working hours away from the family [Kaija, 2013]. Thus, several factors contribute to the leaky pipeline in Uganda to actualise the feminist media theory.

Socio-cultural factors limit the number of girls who take science. It is from those few female scientists that experts on biotechnology (sources), and at times authors, have to emerge.

Historically, women have emerged from their known circumstances to serve as agents for propagation of new ideas, concerns, and cultural trends by distorting, compressing, contesting, and revising history on popular media forums [Nikoloutsos, 2013]. The intention has been to celebrate rather than denigrate women. Such an argument is in the main with post-materialistic values that advance women representation in all sectors of the economy, including science [Stockemer and Sundström, 2016]. Media's underrepresentation of women as contributors and negative portrayal of women as sexual gatekeepers, carers, and subordinates leads to "cultural discourse of madness and insanity" [Meyer, Fallah and Wood, 2011, p. 216]. However, Collins [2011] cautions that initiatives to increase women representation in media roles must avoid perpetrating public stereotypes regarding women that are rife in male-controlled societies. This study is based on newspaper coverage to establish the level of women's representation as authors and sources of stories on a subject related to an activity, agriculture, and specifically the technology of GMOs to be employed in a field where women are majority participants. The objective is to understand the level of women's 
representation in the Ugandan media, both as authors and sources in the GMO stories.

\section{Methodology}

The study is based on a content analysis of 317 articles published over a period of four years in two Ugandan newspapers, the New Vision and the Daily Monitor. The unit of analysis was a news article. The study considered all articles published in a newspaper containing terms such as gene, gene editing, biotech(nology), GMOs, and gene transfer, in relation to plants or food. In addition to capturing the main subject, the researcher coded the expertise and gender of the author(s) and source(s) for each of the chosen articles. Since the unit of analysis was a story, coders categorised stories to have either a dominant male, female or both gender. So, each of the 317 articles fell under one of the three categories. For authors, the stories fell under men only, women only, and shared by-lines. For people quoted as sources, the articles were categorised under men, women and both genders.

The study considered the period starting January 1, 2012 to December 31, 2015. Newspapers were picked for this study because the conversation on GMOs tends to be for the educated, and newspapers are a medium for such individuals. The two mainstream newspapers were selected because the publications tend to be part of every press review for radio and television, thus having a multiplier effect. The starting period is a watershed when Uganda started legislating about 'improving food production' using genetic engineering by drafting the Biotechnology and Biosafety Bill 2012, which journalists baptised the "GMO Bill". Biotechnology (GMOs) is an important topic as it concerns the production of food. The year 2015 is important as it marks the time when the National Resistance Movement (NRM), the ruling party in Uganda pledged its support for the Bill when it was presented on the floor of Parliament [Eyotaru, 2015]. Normally, issues agreed upon in the NRM caucus sail through Parliament, and often become law. However, by the time of writing this article, the Bill had not yet been passed into law because of the antagonism between the pro-and anti-GMO forces which could destabilise the political status quo. In fact, Uganda's President Yoweri Museveni had twice returned the Bill legalising the use of GMOs in Uganda in 2017 and 2018. The purpose of looking at all articles published in the newspaper on the subject of biotechnology, as described above, was to get a more accurate idea of the audience's views (comments and letters to the editor) beyond the news pages. The results were analysed using the Statistical Package for Social Scientists (SPSS) and presented in Table 1 and Figures 1 and 2 in the results section.

The results are presented under gender of the authors of the articles and gender of the sources of articles quoted for general journalists (generalists), members of the public, specialised journalists and specialists in other sectors related to biotechnology that wrote articles in the newspapers. A summary of the findings is presented in Table 1 and Figures 1 and 2.

\section{Women as authors of biotechnology stories}

The study results were analysed in terms of women as generalist journalists covering anything they consider newsworthy, members of the general public, specialised journalists covering biotechnology and GMOs on a regular basis, and as 
Table 1. Gender of the author.

\begin{tabular}{|c|c|c|c|c|c|c|}
\hline \multirow[t]{2}{*}{ Gender } & \multicolumn{5}{|c|}{ Author of the article } & \multirow[t]{2}{*}{ Tota } \\
\hline & Publication & $\begin{array}{l}\text { Generalist } \\
\text { journalist } \\
\text { rarely } \\
\text { covering } \\
\text { GMOs }\end{array}$ & $\begin{array}{l}\text { Member } \\
\text { of general } \\
\text { public }\end{array}$ & $\begin{array}{l}\text { Specialised } \\
\text { journalist } \\
\text { regularly } \\
\text { covering } \\
\text { GMOs }\end{array}$ & $\begin{array}{l}\text { Specialist } \\
\text { (scientist, } \\
\text { science } \\
\text { commu- } \\
\text { nicator) }\end{array}$ & \\
\hline \multirow[t]{2}{*}{$\begin{array}{l}\text { Both female } \\
\text { and male }\end{array}$} & $\begin{array}{l}\text { Daily } \\
\text { Monitor }\end{array}$ & 1 & 3 & 0 & 1 & 5 \\
\hline & Total & 1 & 3 & 0 & 1 & 5 \\
\hline \multirow[t]{3}{*}{ Female } & $\begin{array}{l}\text { Daily } \\
\text { Monitor }\end{array}$ & 11 & 4 & 42 & 6 & 63 \\
\hline & New Vision & 2 & 5 & 1 & 3 & 11 \\
\hline & Total & 13 & 9 & 43 & 9 & 74 \\
\hline \multirow[t]{3}{*}{ Male } & $\begin{array}{l}\text { Daily } \\
\text { Monitor }\end{array}$ & 54 & 36 & 58 & 14 & 162 \\
\hline & New Vision & 7 & 33 & 7 & 13 & 60 \\
\hline & Total & 61 & 69 & 65 & 27 & 222 \\
\hline \multirow[t]{3}{*}{ Undisclosed } & $\begin{array}{l}\text { Daily } \\
\text { Monitor }\end{array}$ & 1 & 12 & 0 & 0 & 12 \\
\hline & New Vision & 0 & 3 & 0 & 0 & 3 \\
\hline & Total & 1 & 15 & 0 & 0 & 16 \\
\hline \multirow[t]{2}{*}{ Total } & $\begin{array}{l}\text { Daily } \\
\text { Monitor }\end{array}$ & 67 & 55 & 100 & 21 & 243 \\
\hline & New Vision & 9 & 41 & 8 & 16 & 74 \\
\hline \multicolumn{2}{|l|}{ Grand total } & 76 & 96 & 108 & 37 & 317 \\
\hline
\end{tabular}

specialists in scientific disciplines or communication officers whose role is to disseminate organisational information. The categorisation is presented in Table 1.

From Table 1 , it can be seen that, overall, $70 \%(n=222)$ of the articles were written by men only, whilst $23 \%(n=74)$ were written by women only. Shared by-lines constituted about $2 \%(n=5)$, but in about $5 \%(n=16)$ of the articles the gender of the authors was unidentifiable, either because the articles did not have by-lines or the coders could not categorise the gender of the author based on the name alone.

In terms of specialisation, $34 \%(n=108)$ of the articles were written by specialised journalists and $23 \%(n=76)$ by generalists (journalists who do not specialise). Articles written by specialists in different fields of science, including communication officers, amounted to $12 \%(n=37)$, a sign that science institutions are beginning to participate in the debate on biotechnology. A significant $31 \%$ $(n=96)$ of the articles came from the public, an indicator of public interest in biotechnology.

Of interest is that 42 of the 43 articles written by specialised female journalists were published in the Daily Monitor; New Vision had only one article. Moreover, only $11 \%(n=7)$ of the articles reported by specialised male journalists were published in the New Vision. Again, $85 \%(n=11)$ of the articles written by female generalists were from the Daily Monitor compared to only $12 \%(n=7)$ of the articles by New Vision male generalists. Worth noting about the context of this statistic is that Daily Monitor had a female reporter whose specialisation was agriculture, and wrote 
most of the stories on GMOs. The difference in the general public's contribution to articles appears marginal, with $56 \%(n=5)$ of the New Vision's articles coming from female readers and $48 \%(n=33)$ of the Daily Monitor's articles coming from male readers. The statistics suggest that there are 43 female journalists, and nine female members of the public who had taken the initiative to understand the subject and contribute as authors in the newspapers. Accounting to funders could be the reason why people (especially anti-GMO activists) in organisations were writing opinions in newspapers.

\section{Articles by sources quoted}

For purposes of understanding women's contribution as experts, it was necessary to look at specialisation of the different sources coded first. On news sources, in at least $39 \%(n=124)$ of the articles, the source of information was missing. The articles were based on the writer's knowledge of the subject, including heresy or belief in conflict with science. Only $27 \%(n=86)$ of articles quoted a biotechnologist as a source of information. When aggregated, $44 \%(n=24)$ of the articles, which quoted biotechnologists, were news stories. The biotechnologists were usually identified as crop breeders or as scientists or experts from the known research institutes. Only $11 \%(n=35)$ of the articles quoted other scientists, such as entomologists, pathologists, soil scientists and agricultural economists on issues of biotechnology. At least $24 \%(n=13)$ of the news articles were published with non-biotechnologists as sources. All included, only $9 \%(n=29)$ had government officials as news sources. These were usually ministers or directors in charge of science and technology. Government officials were usually quoted when the event required opening and closing or during commemorations. Approximately $8 \%$ $(n=25)$ of the sources were from civil society. An equal percentage $(8 \%)$ of the voices of activists often appeared in opinion pages, consultation meetings and event-based stories, where they were proposing alternatives to GMOs. A lower $7 \%$ $(n=22)$ was coded by the general public, whose voices usually appeared in the letters pages. A deeper analysis showed that most of the articles were source-generated by the pro- or anti-GMO actors, through their respective organisations as public relations and outreach departments tried to influence the coverage by staging events, choosing the speakers, and therefore the angling. The percentages are graphically demonstrated in a funnel chart in Figure 1.

As illustrated by the funnel, biotechnologists were priority sources of information when a writer wanted to quote someone in an article. However, their chances were only slightly double those of other scientists who were not experts in

biotechnology. Yet, articles without any source quoted were $39 \%$, one percent more likely to appear in the press than those citing both biotechnologists $(27 \%)$ and other scientists $(11 \%)$ combined. Of the five possible sources quoted in news stories focused on in this study, the general public stood the least chance of being quoted. In a bigger study, an activist argued that the major source of information for the public is "rumours" [Lukanda, 2018, p. 133]. Such findings confirm that most sources of information quoted in the biotechnology contest "are usually partisan" [Mazur, 1981, p. 109]. Additionally, peripheral views "may be lent credibility in mass media", even though the sources may not be trustworthy [Dearing, 1995, p. 341]. Media access, therefore, is a recipe for further controversy since both scientific and maverick ideas use the same channels. It was then necessary to look at how women are represented in stories on GMOs. 


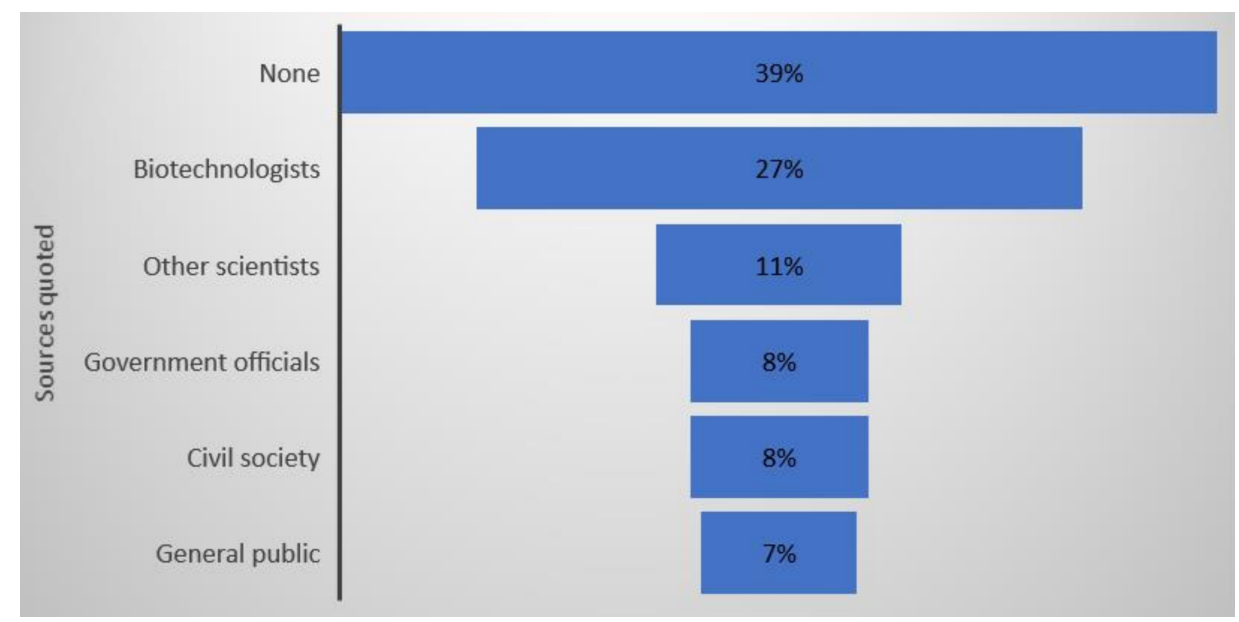

Figure 1. A funnel chart showing the progressively decreasing frequency of sources quoted.

\section{Women as sources of biotechnology stories}

The study took stock of the gender representation of the sources. Generally, nearly half $(n=149)$ of the articles were based on reports and, therefore, the category gender description was not applicable. Approximately one third $(n=92)$ of the articles had male sources. Only $5 \%(n=16)$ of the stories had females only as sources. At least $16 \%(n=51)$ of the articles had both male and female sources in the same article. In some cases, however, it was not possible to identify the gender of the sources based on names only. This was most especially so where the first name and the surname of the sources could be shared by both gender as a common combination. The findings are elaborated on in Figure 2.

From the chart in Figure 2, men alone $(29 \%, n=92)$ were almost six times more likely to be quoted in articles on biotechnology than women alone $(5 \%, n=17)$. But women's chances of being quoted in articles more than tripled if they were to be cited in the same story with men $(16 \%, n=51)$. Moreover, the chances of a biotechnology story quoting a report instead of a person were almost half. Thus, many articles were based on reports alone $(47 \%, n=147)$. The findings confirm

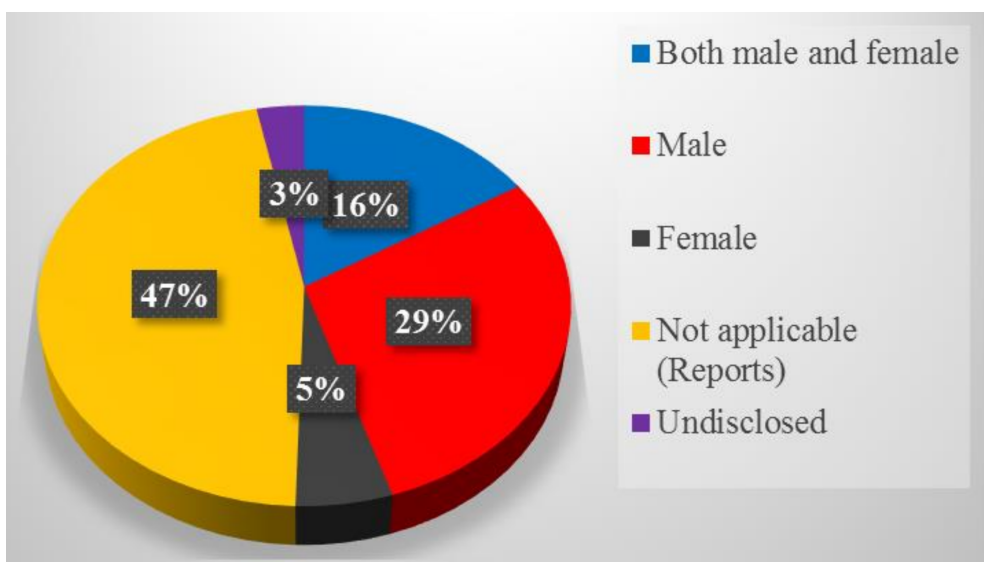

Figure 2. Gender and sources quoted. 
that women as sources of information solely come a distant fourth after reports, men, and both men and women combined. It would be right to argue that men were quoted in stories, and if there was space, women were also quoted.

Of the 317 stories, only $27 \%(n=86)$ quoted biotechnology experts.

Biotechnologists were identified either as GMO breeders, scientists, biosafety expert or researchers from a known research institute. Only two women were quoted in the context of expertise over the four-year period of study. One is a breeder of about 80 years of age, and the other is a biosafety expert doing mainly communications work. Their total appearance in the newspapers constituted only $(12 \%, n=14$ articles) compared to the eight male biotechnologists who appeared in the 72 articles. One of the six journalists interviewed about this issue noted that journalists tend to quote more men "because the women experts are too few, and one of them is of advanced age" [Bendana, 2017].

Also, of interest to the study is that both male and female biotechnologists had positive views about GMOs. This could be because they would be paid for researching, developing GMOs, and expect to share in patent rights. On the other hand, articles written or quoting anti-GMO activists as sources often criticised the technology as inappropriate for Uganda. Although the study did not aggregate the tone of the stories by source, the bigger study from which this paper is extracted established that $83 \%$ of the articles published about GMOs had an element of bias, with 91 negative and 141 positive [Lukanda, 2018, p. 134].

\section{Discussion}

The study reveals that men are more active by way of writing articles, either as journalists or members of the general public. This finding contradicts a recent study that showed that women "express greater concern about GM organisms and are less likely to approve GMOs for consumption than men" [Sarathchandra and McCright, 2017, p. 3]. The difference could probably be attributed to their lower levels of literacy in Uganda, at 68\% compared to that of men at 77.4\% [Uganda Bureau of Statistics, 2016, p. 29]. Even then, the ratios of literacy do not match the low number of stories and opinions published in the two influential newspapers. Therefore, the feminist media theory which explains gender and related gendered power relations in communicative contexts holds [Steinke, 1998; McIntosh, 2014]. By implication masculinity interests limit women's participation on some media platforms as sources, authors, and as audience. Factors that particularly affect women in Uganda include; household poverty, poor menstrual hygiene in schools, inadequate school fees, shortage of learning tools in schools, and poor attitude of some parents toward educating the girls. While the stated factors contribute to dropping out of school for both boys and girls, Shahidul and Zehadul Karim [2015] argue that, female students are the most affected. Wodon, Nguyen and Tsimpo [2016] demonstrate that child marriage reduces secondary school enrolment and completion for girls as socio-cultural factors favour early child marriage to schooling, even though Ugandan law prohibits marriage before 18 years. Such factors limit the number of would be authors and sources for biotechnology stories.

Although not many studies were found on the status of women journalists in Ugandan newsrooms [Nassanga, 1997; Semujju, 2015], a more recent study has demonstrated that the clear difference in the treatment of male and female journalists continues, as women are still marginalised in decision-making positions 
[Maractho, 2019]. women writers in Ugandan newspapers stand at $13 \%$ and women as sources are 20\% [Global Media Monitoring Project, 2015, p. 8]. In the context of this study, the higher percentages of participation of women as reporters was a result of individual initiative since the by-lines belonged to a few female journalists. Moreover, the female sources were quoted repeatedly, for lack of expert options. The results of this study are consistent with findings from other countries. Whereas the number of female journalists covering hard news stories such as politics, business and crime is recognisable, most "female reporters remain pigeon-holed in those traditionally female story areas" of health, entertainment, and education [North, 2016, p. 356]. The study seems to posit that a deep gender bias and feminisation prevent women from covering hard news and science subjects. Possibly, when GMOs become a key health issue, more women would start covering it.

However, North's results, which imply that a surge in the number of women in the newsrooms leads to the feminisation of news, may not apply to Uganda, where the editorial section of the biggest multimedia newsroom, Vision Group, was headed by a woman at the time of this research. No local study was found to establish the number of journalists, and their gender distribution across the country to add context to the current study. Further, Nation Media Group's television station, NTV Uganda, had a woman as its managing director from 2013 to 2017. At the same time, Uganda has for close to two decades been home to Africa's first women's radio, Mama FM, started by the Uganda Media Women's Association (UMWA). Additionally, Uganda's only two full-professors of journalism are women. In addition, marginalisation in the media industry and the public sphere cannot be dismissed based only on these facts. The explanation for fewer stories about biotechnology being posited by female reporters may then lie outside the newsroom, as feminist media theory suggests, and such socio-cultural factors may be a subject for deeper research.

Furthermore, the finding that men were more likely to be used as sources in stories on biotechnology is consistent with results from related studies. Women are at best underrepresented as sources of information for news and, at worst, voiced as victims, or as associates of men in the news, or used as decoration, especially in photographs accompanying science stories [González et al., 2017; Ross and Carter, 2011; Zoch and Turk, 1998]. The underrepresentation is evident in science academies [Ngila et al., 2017, pp. 3-4] and registration of patents [Organisation for Economic Co-operation and Development, 2017]. Moreover, women science graduates are less likely than men to work as professionals in their fields due to sexual harassment in the work environments [McIntosh, 2014], and the inadequacy in implementation of gender policies to allow them to stay in school, become scientists if they want, and thrive in workplaces to stand a chance to be sources and authors. This outcome suggests that, as in politics, women scientists struggle to break the structural institutional, professional and economic stereotypical challenges facilitated by the macho culture of mainstream media that posits them as a powerless group, thereby perpetrating gender-based hostility that marginalises them in science stories. Articles on genetics tend to "reflect social biases and assumptions" beyond being male or female [Petersen, 2001, p. 1257]. Structural factors freeze women out of the clusters of prominent people likely to be sought by journalists as news sources on biotechnology [Ross and Carter, 2011]. Besides, the attrition of females from the newsrooms is higher because the practice of 
journalism does not seem appealing to women [Kaija, 2013]. Therefore, structural factors contribute significantly to women's underrepresentation in the media both as authors and sources, and such a scenario can have serious implications.

Implication for science communication in Uganda
The implication is that without deliberate efforts to seek the voices of female scientists, women's expert voices will continue to be underrepresented in biotechnology stories. From the results and the discussion, training more female journalists in covering biotechnology is important if the gender schema is to be altered. Equally important is training more female biotechnologists to provide a voice on GMOs when journalists need to seek opinions on such a subject. It is expected that more female journalists will seek the underrepresented female experts and other voices. Such initiatives will not only increase the authors and sources of information in the news, but will also increase diversity in the newspapers and other media platforms.

Additionally, it is imperative to train journalists in identifying gender perspectives in science. Particularly, journalists need to learn to link women's interests to the socio-cultural and political implications of the uptake of GMOs. Gender balance can only be achieved if the interests of women, and the role women play in the food production are seen in the context of the undeniably patriarchal Ugandan society. In the context of Uganda, as earlier stated, 76 percent of all women are involved in agriculture compared to 65\% men [World Bank, 2019].

The emphasis on training journalists only makes sense if their most important source of information on GMOs, the scientists, are nurtured in collaborating with the media in reaching the most important constituency of knowledge - the public - who apply the knowledge scientists generate in their laboratories. Yet, deliberate collaborations between female and male scientists will also be necessary for women experts to stand higher chances of providing a voice on biotechnology since the field already has more men as experts. Indeed, media platforms help scientists account to the taxpayers who fund a lot of the scientific work, including biotechnology. Women expert and non-expert voices are important on the controversial science of GMOs as decisions on the application of such science is usually based on political interests rather than scientific findings.

Therefore, (female) scientists need media training to make them more capable and confident in dealing with journalists. Such training will give them leverage and enable them to authoritatively write in newspapers and speak about the subject of GMOs, hence increase their presence both as authors and sources of stories on biotechnology and GMOs.

As it appears, the nature of science, the media logic and social-cultural factors side-line women in the news and the public sphere, in relation to the debate on GMOs. The findings indicate that increase in women's representation is pegged on the mercy of men who dominate decision-making not only in the newsrooms, but also in science institutions, and society generally. While deploying female journalists seems to be a solution to increasing women voices in the newspapers, this study concludes that it is imperative to sensitise journalists about the challenge 
of marginalisation as the present situation suggests stories with both men and women as sources quoted are more than those where women are the sole sources. Also, important, is the need for female scientists to collaborate with their male counterparts and journalists so as to increase their visibility in the media on an agricultural sector where women are great contributors to the labourforce. Therefore, looking at GMOs from a gender perspective is likely to generate more representative societal issues than if GMOs are looked at in commercial, health, ethical, and environmental standpoints only.

\section{Limitations}

\section{References}

Araújo, E. B., Araújo, N. A. M., Moreira, A. A., Herrmann, H. J. and Andrade, J. S. (2017). 'Gender differences in scientific collaborations: women are more egalitarian than men'. PLOS ONE 12 (5), e0176791. https://doi.org/10.1371/journal. pone.0176791.

Armstrong, C. L. (2004). 'The influence of reporter gender on source selection in newspaper stories'. Journalism \& Mass Communication Quarterly 81 (1), pp. 139-154. https://doi.org/10.1177/107769900408100110.

Atekyereza, P. R. (2001). 'The education of girls and women in Uganda'. Journal of Social Development in Africa 16 (2), pp. 115-146. https://doi.org/10.4314/jsda.v16i2.23876.

Bauer, M. W. (2002). ‘Controversial medical and agri-food biotechnology: a cultivation analysis'. Public Understanding of Science 11 (2), pp. 93-111. https://doi.org/10.1088/0963-6625/11/2/301.

Bayer Global (2020). Unlocking the hidden potential: biotechnology and GMOs. URL: https://www . bayer .com/en/crop-science/crop-science-innovationsbiotech-gmos (visited on 2nd October 2020).

Bendana, C. (2017). Telephone interview conducted March 5, 2017.

Bhatta, A. and Misra, K. D. (2016). 'Biotechnology communication needs a rethink'. Current Science 110 (4), pp. 573-578.

URL: https://www . jstor.org/stable/24907918.

Blickenstaff, J. C. (2005). ‘Women and science careers: leaky pipeline or gender filter?' Gender and Education 17 (4), pp. 369-386. https://doi.org/10.1080/09540250500145072.

Ceci, S. J., Williams, W. M. and Barnett, S. M. (2009). 'Women's underrepresentation in science: sociocultural and biological considerations'. Psychological Bulletin 135 (2), pp. 218-261. https://doi.org/10.1037/a0014412.

Chimba, M. and Kitzinger, J. (2010). 'Bimbo or boffin? Women in science: an analysis of media representations and how female scientists negotiate cultural contradictions'. Public Understanding of Science 19 (5), pp. 609-624. https://doi.org/10.1177/0963662510377233.

Collins, R. L. (2011). 'Content analysis of gender roles in media: where are we now and where should we go?' Sex Roles 64 (3-4), pp. 290-298. https://doi.org/10.1007/s11199-010-9929-5.

Cuklanz, L. (2016). 'Feminist theory in communication'. In: The International Encyclopedia of Communication Theory and Philosophy. John Wiley \& Sons. https://doi.org/10.1002/9781118766804.wbiect157. 
Dearing, J. W. (1995). ‘Newspaper coverage of maverick science: creating controversy through balancing'. Public Understanding of Science 4 (4), pp. 341-361. https://doi .org/10.1088/0963-6625/4/4/002.

Eyotaru, O. (2015). ‘NRM caucus endorses GMO bill'. Uganda Radio Network. URL: h ttps://ugandaradionetwork.com/story/nrm-caucus-endorses-gmo-bill (visited on 19th April 2021).

Food and Agricultural Organisation (2011). The state of food and agriculture 2010-2011 - Women in agriculture: closing the gender gap for development. Food and Agricultural Organisation of the United Nations.

URL: https://reliefweb.int/report/world/state-food-and-agriculture-2 010-2011-women-agriculture-closing-gender-gap-development.

Giordano, S. (2017). 'Those who can't, teach: critical science literacy as a queer science of failure'. Catalyst: Feminism, Theory, Technoscience 3 (1), pp. 1-21. https://doi.org/10.28968/cftt.v3i1.28790.

Global Media Monitoring Project (2015). Who makes the news? London, U.K.: World Association for Christian Communication. URL: http://www.media-diversity.org/additional-files/Who_Makes_the_N ews_-_Global_Media_Monitoring_Project.pdf.

González, D., Mateu, A., Pons, E. and Domínguez, M. (2017). 'Women scientists as decor: the image of scientists in Spanish press pictures'. Science Communication 39 (4), pp. 535-547. https: //doi.org/10.1177/1075547017719074.

Hafkin, N. J. (2016). National assessments on gender and science, technology and innovation. A review of four country assessments from East Africa: Ethiopia, Kenya, Rwanda and Uganda. Ontario, Canada: Women in Global Science and Technology, pp. 1-27.

Hill, C., Corbett, C. and St. Rose, A. (2010). Why so few? Women in science, technology, engineering, and mathematics. Washington, DC, U.S.A.: American Association of University Women.

Ioannidou, E. and Rosania, A. (2015). 'Under-representation of women on dental journal editorial boards'. PLoS ONE 10 (1), e0116630. https://doi.org/10.1371/journal . pone.0116630.

Kaija, B. (2013). 'Uganda: women near parity but still leaving newsrooms'. In: The Palgrave International Handbook of Women and Journalism. Ed. by C. M. Byerly. London, U.K.: Palgrave Macmillan, pp. 315-329. https://doi.org/10.1057/9781137273246_23.

Kenney, M. (2018). 'Mattering: feminism, science, and materialism'. New Genetics and Society 37 (2), pp. 181-185. https://doi.org/10.1080/14636778.2017.1331732.

Knobloch-Westerwick, S., Glynn, C. J. and Huge, M. (2013). 'The Matilda effect in science communication: an experiment on gender bias in publication quality perceptions and collaboration interest'. Science Communication 35 (5), pp. 603-625. https://doi.org/10.1177/1075547012472684.

Lukanda, N. I. (2018). 'From lab to fork? Press coverage and public (mis)perception of crop biotechnology in Uganda'. Ph.D. Thesis. Stellenbosch, South Africa: Stellenbosch University.

Maractho, E. C. (2019). '(Re)producing cultural narratives on women in public affairs programmes in Uganda'. Journal of African Media Studies 11 (3), pp. 293-311. https://doi.org/10.1386/jams_00002_1.

Mazur, A. (1981). 'Media coverage and public opinion on scientific controversies'. Journal of Communication 31 (2), pp. 106-115. https://doi.org/10.1111/j.1460-2466.1981.tb01234.x.

McCook, A. (2013). 'Women in biotechnology: barred from the boardroom'. Nature 495 (7439), pp. 25-27. https : //doi .org/10.1038/495025a. 
McIntosh, H. (2014). 'Representations of female scientists in The Big Bang Theory'. Journal of Popular Film and Television 42 (4), pp. 195-204.

https://doi.org/10.1080/01956051.2014.896779.

Mendick, H. and Moreau, M.-P. (2013). 'New media, old images: constructing online representations of women and men in science, engineering and technology'. Gender and Education 25 (3), pp. 325-339.

https://doi.org/10.1080/09540253.2012.740447.

Merton, R. K. (1968). 'The Matthew effect in science. The reward and communication systems of science are considered'. Science 159 (3810), pp. 56-63. https://doi.org/10.1126/science.159.3810.56.

Meyer, M. D. E., Fallah, A. M. and Wood, M. M. (2011). ‘Gender, media, and madness: reading a rhetoric of women in crisis through Foucauldian theory'. Review of Communication 11 (3), pp. 216-228. https://doi.org/10.1080/15358593.2011.578254.

Miller, D. I., Eagly, A. H. and Linn, M. C. (2015). 'Women's representation in science predicts national gender-science stereotypes: evidence from 66 nations'. Journal of Educational Psychology 107 (3), pp. 631-644. https://doi.org/10.1037/edu0000005.

Ministry of Education and Sports (2017). Education Abstract 2017. Kampala, Uganda: MOES. URL: http://www.education.go.ug/wp-content/uploads/201 9/08/Abstract-2017.pdf.

Moss-Racusin, C. A., Sanzari, C., Caluori, N. and Rabasco, H. (2018). 'Gender bias produces gender gaps in STEM engagement'. Sex Roles 79 (11-12), pp. 651-670. https://doi.org/10.1007/s11199-018-0902-z.

Nassanga, L. G. (1997). 'Women, development and the media: the case for Uganda'. Media, Culture E Society 19 (3), pp. 471-476. https://doi.org/10.1177/016344397019003010.

National Academies of Sciences, Engineering, and Medicine (2020). Promising practices for addressing the underrepresentation of women in science, engineering, and medicine: opening doors. Ed. by R. Colwell, A. Bear and A. Helman. Washington, DC, U.S.A.: The National Academies Press. URL: https://www . nap. edu/read/25585/chapter/1.

Ngila, D., Boshoff, N., Henry, F., Diab, R., Malcom, S. and Thomson, J. (2017). 'Women's representation in national science academies: an unsettling narrative'. South African Journal of Science 113 (7/8), \#2017-0050. https://doi.org/10.17159/sajs.2017/20170050.

Niemi, M. K. and Pitkänen, V. (2017). 'Gendered use of experts in the media: analysis of the gender gap in Finnish news journalism'. Public Understanding of Science 26 (3), pp. 355-368. https: //doi .org/10 .1177/0963662515621470.

Nikoloutsos, K. P. (2013). Ancient Greek women in film. 1st ed. Oxford, U.K.: Oxford University Press. https://doi.org/10.1093/acprof: oso/9780199678921.001.0001.

North, L. (2016). 'The gender of "soft" and "hard" news: female journalists' views on gendered story allocations'. Journalism Studies 17 (3), pp. 356-373. https://doi.org/10.1080/1461670X.2014.987551.

Odaga, G. (2020). 'Gender in Uganda's tertiary educational distribution'. Social Sciences \& Humanities Open 2 (1), 100023. https://doi.org/10.1016/j.ssaho.2020.100023.

Organisation for Economic Co-operation and Development (2017). 'Report on the implementation of the OECD gender recommendations - Some progress on gender equality but much left to do'. In: Meeting of the OECD Council at Ministerial Level (Paris, France, 7th-8th June 2017).

URL: http: //www . oecd.org/mcm/documents/C-MIN-2017-7-EN . pdf. 
Osborne, J., Simon, S. and Collins, S. (2003). 'Attitudes towards science: a review of the literature and its implications'. International Journal of Science Education 25 (9), pp. 1049-1079. https://doi.org/10.1080/0950069032000032199.

Palacios-Lopez, A., Christiaensen, L. and Kilic, T. (2015). 'How much of the labor in African agriculture is provided by women?' Policy Research Working Papers, 7282. https://doi .org/10.1596/1813-9450-7282. (Visited on 3rd September 2020).

Petersen, A. (2001). 'Biofantasies: genetics and medicine in the print news media'. Social Science \& Medicine 52 (8), pp. 1255-1268. https://doi.org/10.1016/S0277-9536(00)00229-X.

Pietri, E. S., Moss-Racusin, C. A., Dovidio, J. F., Guha, D., Roussos, G., Brescoll, V. L. and Handelsman, J. (2017). 'Using video to increase gender bias literacy toward women in science'. Psychology of Women Quarterly 41 (2), pp. 175-196. https://doi.org/10.1177/0361684316674721.

Rosenberger, N. (2009). 'Global food terror in Japan: media shaping risk perception, the nation, and women'. Ecology of Food and Nutrition 48 (4), pp. 237-262. https://doi.org/10.1080/03670240903001100.

Ross, K. and Carter, C. (2011). 'Women and news: a long and winding road'. Media, Culture $\mathcal{E}$ Society 33 (8), pp. 1148-1165. https://doi.org/10.1177/0163443711418272.

Rossiter, M. W. (1993). 'The Matthew Matilda effect in science'. Social Studies of Science 23 (2), pp. 325-341. https: //doi.org/10.1177/030631293023002004.

Sarathchandra, D. and McCright, A. M. (2017). 'The effects of media coverage of scientific retractions on risk perceptions'. SAGE Open 7 (2), pp. 1-11. https://doi.org/10.1177/2158244017709324.

SEEK-GSP (2016). 'Women scientists face down men in developing world'. SEEK-GSP. URL: http://seek-gsp.org/women-scientists-face-down-men-in -developing-world/ (visited on 4th September 2020).

Sell, M. and Minot, N. (2018). 'What factors explain women's empowerment? Decision-making among small-scale farmers in Uganda'. Women's Studies International Forum 71, pp. 46-55. https://doi.org/10.1016/j.wsif.2018.09.005.

Semujju, B. (2015). 'Frontline farmers, backline sources: women as a tertiary voice in climate change coverage'. Feminist Media Studies 15 (4), pp. 658-674. https://doi.org/10.1080/14680777.2014.946942.

Shachar, O. (2000). 'Spotlighting women scientists in the press: tokenism in science journalism'. Public Understanding of Science 9 (4), pp. 347-358. https://doi.org/10.1088/0963-6625/9/4/301.

Shahidul, S. M. and Zehadul Karim, A. H. M. (2015). 'Factors contributing to school dropout among the girls: a review of literature'. European Journal of Research and Reflection in Educational Sciences 3 (2), pp. 25-36.

Steiner, L. (2014). 'Feminist media theory'. In: The handbook of media and mass communication theory. Ed. by R. S. Fortner and P. M. Fackler. Vol. 1. John Wiley \& Sons, pp. 359-379. https://doi.org/10.1002/9781118591178. ch20.

Steinke, J. (1998). 'Theory into practice: connecting theory and practice: women scientist role models in television programming'. Journal of Broadcasting $\mathcal{E}$ Electronic Media 42 (1), pp. 142-151. https://doi.org/10.1080/08838159809364439.

Steinpreis, R. E., Anders, K. A. and Ritzke, D. (1999). 'The impact of gender on the review of the curricula vitae of job applicants and tenure candidates: a national empirical study'. Sex Roles 41 (7-8), pp. 509-528.

https://doi.org/10.1023/a:1018839203698. 
Stockemer, D. and Sundström, A. (2016). 'Modernization theory: how to measure and operationalize it when gauging variation in women's representation?' Social Indicators Research 125 (2), pp. 695-712. https://doi.org/10.1007/s11205-014-0844-y.

Suarez-Villa, L. (2000). Invention and the rise of technocapitalism. Lanham, MD, U.S.A.: Rowman \& Littlefield.

Subramaniam, B. (2009). 'Moored metamorphoses: a retrospective essay on feminist science studies'. Signs: Journal of Women in Culture and Society 34 (4), pp. 951-980. https://doi.org/10.1086/597147.

Uganda Bureau of Statistics (2012). Uganda Demographic and Health Survey 2011. Kampala, Uganda: UBOS. URL: https://dhsprogram.com/pubs/pdf/fr264/fr264.pdf.

- (2016). National population and housing census 2014 - Main report. Kampala, Uganda: UBOS, pp. 50-80. URL: https : //www . ubos . org (visited on 5th October 2017).

- (2019). National mid year population projections by single age (2015-2050). Kampala, Uganda: UBOS. URL: https: //www . ubos . org/?s=projections.

United Nations Educational, Scientific and Cultural Organisation (2019). Strengthening gender responsive pedagogy for STEM in Uganda. URL: https : //en . u nesco.org/news/strengthening-gender-responsive-pedagogy-stem-uganda.

Walsh, C. (2015). 'Media capital or media deficit? Representations of women in leadership roles in old and new media'. Feminist Media Studies 15 (6), pp. 1025-1034. https://doi.org/10.1080/14680777.2015.1087415.

Wodon, Q., Nguyen, M. C. and Tsimpo, C. (2016). 'Child marriage, education, and agency in Uganda'. Feminist Economics 22 (1), pp. 54-79. https://doi.org/10.1080/13545701.2015.1102020.

World Bank (2019). Employment in agriculture, female (\% of female employment) (modeled ILO estimate). International Labour Organization, ILOSTAT database. URL: https://data.worldbank.org/indicator/SL. AGR. EMPL.FE.ZS (visited on 17th March 2020).

Zoch, L. M. and Turk, J. V. (1998). 'Women making news: gender as a variable in source selection and use'. Journalism E Mass Communication Quarterly 75 (4), pp. 762-775. https://doi.org/10.1177/107769909807500410.

Author

Lecturer, Department of Journalism and Communication Makerere University. Research Fellow, Department of Journalism Stellenbosch University, South Africa. E-mail: ivanlukanda@gmail.com.

\section{How to cite}

Lukanda, I. N. (2021). 'Female voices marginalised in media coverage of science in Uganda, both as authors and sources'. JCOM 20 (02), A11. https://doi.org/10.22323/2.20020211. 